\title{
Pax6 and Engrailed 1 Regulate Two Distinct Aspects of Renshaw Cell Development
}

\author{
Tamar Sapir, ${ }^{1}$ Eric J. Geiman, ${ }^{1,2}$ Zhi Wang, ${ }^{3}$ Tomoko Velasquez, ${ }^{1}$ Sachiko Mitsui, ${ }^{4}$ Yoshihiro Yoshihara, ${ }^{4}$ Eric Frank, ${ }^{3}$ \\ Francisco J. Alvarez, ${ }^{2}$ and Martyn Goulding ${ }^{1}$ \\ ${ }^{1}$ Molecular Neurobiology Laboratory, The Salk Institute, La Jolla, California 92037, ${ }^{2}$ Department of Anatomy, Wright State University, Dayton, Ohio 45435, \\ ${ }^{3}$ Department of Neurobiology, University of Pittsburgh, Pittsburgh, Pennsylvania 15261, and ${ }^{4}$ Laboratory for Neurobiology of Synapse, The Institute of \\ Physical and Chemical Research (RIKEN) Brain Science Institute, Wako, Saitama 351-0198, Japan
}

\begin{abstract}
Many of the interneuron cell types present in the adult spinal cord contribute to the circuits that control locomotion and posture. Little is known, however, about the embryonic origin of these cell types or the molecular mechanisms that control their differentiation. Here we provide evidence that V1 interneurons (INs), an embryonic class of interneurons that transiently express the En1 transcription factor, differentiate as local circuit inhibitory interneurons and form synapses with motor neurons. Furthermore, we show that a subset of V1 INs differentiates as Renshaw cells, the interneuronal cell type that mediates recurrent inhibition of motor neurons. We analyze the role that two V1 IN-related transcription factor genes play in Renshaw cell development. Pax6 ( paired box gene 6) is necessary for an early step in Renshaw cell development, whereas Engrailed 1 (En1), which is genetically downstream of Pax6, regulates the formation of inhibitory synapses between Renshaw cells and motor neurons. Together, these results show that Pax6 and En 1 have essential roles in establishing the recurrent inhibitory circuit between motor neurons and Renshaw cells.
\end{abstract}

Key words: spinal cord development; Renshaw cells; recurrent inhibition; En1; Pax6; V1 interneurons

\section{Introduction}

Recent studies have identified five early classes of neurons in the ventral neural tube: motor neurons and four ventral interneuron (IN) subtypes: V0, V1, V2, and V3 INs (Briscoe et al., 2000; Jessell, 2000). The adult neuronal cell types generated from these five early neuronal classes are likely to be major constituents of the circuits that control posture and locomotion (Jessell, 2000; Goulding et al., 2002). Although significant progress has been made in characterizing some embryonic interneuron cell types (Saueressig et al., 1999; Wenner et al., 2000; Moran-Rivard et al., 2001), the relationship between embryonic interneurons and physiologically defined cell types in the adult spinal cord is not known. In this study we focus on the V1 embryonic IN subgroup. V1 INs arise from $\mathrm{Pax6}^{+} / \mathrm{Dbx} 2^{+} / \mathrm{Nkx6} 62^{+}$progenitors, and they transiently express En1 (Matise and Joyner, 1997; Saueressig et al., 1999; Vallstedt et al., 2001). V1 INs populate the ventral horn, and they comprise a distinct morphological class of interneuron (Saueressig et al., 1999; Goulding et al., 2002). V1 INs express

\footnotetext{
Received July 4, 2003; revised Dec. 9, 2003; accepted Dec. 12, 2003.

This research was supported by grants from the National Institutes of Health to M.G. and E.F., from the Christopher Reeve Paralysis Foundation to T.S. and M.G., and from the National Science Foundation to F.J.A. We thank Tom Jessell, Alexandra Joyner, and Sam Pfaff for antibodies; Wolfgang Wurst for the En 1 knock-in targeting cassette; Phil Soriano for the ROSA26 constructs; and Jeff Mann for ES cells. We also thank Lauren Clancey and David Finn for technical assistance with genotyping mice.

Correspondence should be addressed to Martyn Goulding, Molecular Neurobiology Laboratory, The Salk Institute, La Jolla, CA 92037. E-mail: goulding@salk.edu.

Z. Wang's and E. Frank's present address: Department of Physiology, Tufts University, Boston, MA 02111.

T. Sapir's present address: Molecular Genetics, Weizmann Institute of Science, Rehovot, 76100 Israel.

D0I:10.1523/JNEUROSCI.3187-03.2004

Copyright $\odot 2004$ Society for Neuroscience $\quad$ 0270-6474/04/241255-10\$15.00/0
}

GAD65, and their locally projecting axons are closely opposed to motor neurons (Saueressig et al., 1999).

Several classes of interneurons in the ventral spinal cord reduce motor neuron excitability (Burke, 1998; Jankowska, 2001). One such class is the Renshaw cell (Renshaw, 1946), which is thought to play key roles in fine-tuning motor output by modulating motor neuron recruitment and proprioceptive reflexes. Renshaw cells receive strong excitatory innervation from motor neuron axon collaterals and in turn inhibit motor neurons, as well as Ia inhibitory INs, via synapses that use both glycine and GABA (Eccles et al., 1954; Hultborn et al., 1971; Cullheim and Kellerth, 1982; Arvidsson et al., 1992; Schneider and Fyffe, 1992; Alvarez et al., 1999). Renshaw cells also display unique synaptic and neurochemical characteristics that permit their histological identification in the developing postnatal and adult spinal cord (Alvarez et al., 1997, 1999; Geiman et al., 2000, 2002; Dourado and Sargent, 2002).

Previous studies in the embryonic chick spinal cord identified some Engrailed $1\left(E n 1^{+}\right)$neurons with synaptic inputs from motor neurons, suggesting that they may be equivalent to Renshaw cells (Wenner et al., 2000). Here we use Cre-mediated recombination (Rajewsky et al., 1996) to identify the differentiated progeny of $\mathrm{En} 1^{+} \mathrm{V} 1 \mathrm{INs}$ and ascertain whether they include Renshaw cells. We show that V1 INs are GABAergic and establish monosynaptic connections with motor neurons. A subset of V1 INs is contacted by motor neuron collaterals, and they exhibit the neuroanatomical features of Renshaw cells. Moreover, we find that Renshaw cells are derived exclusively from V1 INs. In Pax6 ( paired box gene 6) mutant mice, Renshaw cells are absent, indicating that Pax6 is necessary for the differentiation of this inter- 
neuron cell type. En1 mutant mice have normal numbers of Renshaw cells. However, these Renshaw cells make fewer recurrent inhibitory connections with motor neurons. These findings demonstrate that Pax6 and En1 regulate two key steps in the developmental program of Renshaw cells.

\section{Materials and Methods}

Generation of En1 ${ }^{\text {Cre }}$ knock-in mice. An En1 ${ }^{\text {Cre }}$ targeting vector was created by inserting a Cre PGK-neopA cassette to the first coding exon of En1, using a strategy similar to that of Hanks et al. (1995). The endogenous ATG and sequences coding for the first 72 amino acids of $E n 1$ were replaced with a Cre gene cassette, creating a null allele. The targeting vector was electroporated into W9.5 embryonic stem (ES) cells, and resistant clones were selected by using standard techniques (Joyner, 1993). ES cells were screened for homologous recombination by using an external 3' genomic probe (Saueressig et al., 1999). One of two recombinant ES cell clones when injected to C57B16 blastocysts (B11) gave germline transmission. Genotyping of the En1 ${ }^{\text {Cre }}$ allele was done by PCR, using Cre-specific primers (Cre3, TAATCGCCATCTTCCAGCAG; Cre4, CAATTTACTGACCGTACAC).

Generation of R26 GAP43-EGFP mice. We generated the R26 GAP43-EGFP targeting vector, by inserting a cassette containing a SA loxP-PGKneotpA-loxP "stop sequence," followed by a GAP43-EGFP/pA gene, into the unique $\mathrm{XbaI}$ site of a $5 \mathrm{~kb}$ genomic fragment from the R26locus, $\sim 300 \mathrm{bp}$ $5^{\prime}$ to the original gene trap integration site. This same strategy has been used to generate the $R 26^{\text {lac } Z}$ reporter (Soriano, 1999). The targeting vector was electroporated to W9.5 ES cells, and G418-resistant clones were isolated and screened by using a $5^{\prime}$ internal probe spanning the short arm (1 kb SacII-XbaI fragment). Two of four recombinant clones were injected to C57Bl6 blastocysts and gave germline transmission. PCR genotyping was performed with enhanced green fluorescent protein (EGFP)specific primers (EGFP-1, GACGTAAACGGCCACAAGTT; EGFP-2, GAACTCCAGCAGGACCATGT) and primers specific for the R26 locus (Soriano, 1999).

Immunohistochemistry. Anti- $\beta$-galactosidase antibodies were raised in rat against a His-tagged fusion protein that included 105 amino acids of the $L b x 1 \mathrm{~N}$ terminus fused to a full-length Escherichia coli $\beta$-galactosidase ( $\beta$-gal). Lbx1 immunoreactivity was eliminated by absorbing the antisera to recombinant Lbx1 protein (Gross et al., 2002). Antibodies to En1 (rabbit polyclonal) and HB9 (rabbit polyclonal) were provided by Drs. Alexandra Joyner and Sam Pfaff, respectively. Commercially available antibodies to the following proteins were used: En1 (mouse monoclonal; Developmental Studies Hybridoma Bank, Iowa City, IA), $\beta$-gal (rabbit polyclonal; Cappel, West Chester, PA), GFP (rabbit polyclonal; Molecular Probes, Eugene, OR), calbindin D28K (rabbit polyclonal; Swant, Bellinzona, Switzerland), gephyrin (mouse monoclonal 7a; Boehringer Mannheim, Indianapolis, IN), vesicular acetylcholine transporter (VAChT; goat polyclonal, Pharmingen, San Diego, CA), choline acetyltransferase (ChAT; goat polyclonal, Chemicon, Temecula, CA), GABA (rabbit polyclonal; Chemicon), $\alpha 4$ subunit of the nicotinic acetylcholine receptor (NAcR $\alpha 4$; rabbit polyclonal, Chemicon), and wheat germ agglutinin (WGA; rabbit polyclonal; Sigma, St. Louis, MO). Primary antibodies were preabsorbed with $1 \%$ embryonic day 17 (E17) mouse embryo powder before use. Immunoreactivity was detected with secondary antibodies conjugated to FITC, Cy3, TRITC, or Cy5 (Jackson ImmunoResearch, West Grove, PA).

Postnatal spinal cords from animals perfused with $4 \%$ paraformaldehyde were postfixed for $30 \mathrm{~min}$ to $1 \mathrm{hr}$ in the same fixative. Embryonic spinal cords were dissected out of the animal and fixed with $4 \%$ paraformaldehyde. Spinal cords were cryoprotected with $15 \%$ sucrose overnight. Frozen sections were cut and processed for staining either as freefloating sections (older spinal cords) or on slides (neonatal and embryonic spinal cords). The immunocytochemical protocols used were as previously reported (Saueressig et al., 1999; Geiman et al., 2000). Analysis was performed with either a Leica TCS confocal system (Nussloch, Germany) or a Zeiss LSM 510 confocal microscope (Oberkochen, Germany).

Retrograde labeling with conjugated dextrans. E13.5 mouse embryos were collected and dissected ventrally to expose the spinal cord. After dissection, two unilateral cuts $1 \mathrm{~mm}$ apart were place in the ventral spinal cord at the L3-L4 level. Then a fluorescein-conjugated dextran crystal (Molecular Probes) was inserted to the caudal cut site while a rhodamine-conjugated dextran (Molecular Probes) crystal was inserted in the rostral cut site (Glover, 1995). For postnatal day 4 (P4) labelings one side of the spinal cord was cut at the level of L3, and a crystal of fluorescein-conjugated dextran was inserted into the cut site. Embryos and isolated spinal cords were incubated in oxygenated transport solution (Gross et al., 2002) for $8 \mathrm{hr}$ to allow for transport. Embryos and spinal cords were fixed for $30 \mathrm{~min}$ in $4 \%$ paraformaldehyde/PBS, and the sections stained with an antibody to calbindin D28K. Consecutive sections were analyzed with a Zeiss LSM 510 confocal microscope.

Transsynaptic tracing labeling with TTC-lacZ and TTC-EGFP. pGEX: TTC-lacZ (Coen et al., 1997) or pGEX:TTC-EGFP (this study) were transfected to E. coli strain BL-21. Recombinant protein was purified over glutathione-agarose (Sigma). GST fusion proteins were eluted by thrombin (Sigma) and concentrated. P0-P4 animals were injected with the recombinant purified protein. Each animal was injected with $\sim 100-$ $150 \mu \mathrm{g}$ of protein $(5 \mu \mathrm{l})$ into the target muscles (see Results). Animals were kept alive for $4-24 \mathrm{hr}$ to facilitate transport of the tetanus toxin C subunit (TTC) fusion protein. Mice were killed by intracardiac perfusion of $4 \%$ paraformaldehyde in PBS while under deep anesthesia $(2.5 \%$ Avertin). Spinal cords were removed, postfixed in $4 \%$ paraformaldehyde/PBS, and processed for cryo-sectioning or vibratome sectioning.

Electrophysiology. Intracellular electrical recordings were made from spinal motor neuron populations in E18.5 embryos. Spinal cords were hemisected along the vertical midline and maintained at $30^{\circ} \mathrm{C}$ in oxygenated saline (Mears and Frank, 1997; Arber et al., 2000). Intracellular pipettes were filled with $2 \mathrm{M} \mathrm{KCl}$ and $500 \mu \mathrm{M}$ QX314 to block antidromic action potentials from invading the cell soma. Electrical stimuli were applied to the ventral roots via suction electrodes to stimulate Renshaw cells antidromically and identify motor neurons. Glutamatergic synaptic inputs were blocked with $20 \mu \mathrm{M}$ CNQX and $50 \mu \mathrm{M}$ AP5 in all recordings. Glycine/GABA-mediated synaptic potentials became depolarizing during each recording as $\mathrm{Cl}^{-}$diffused from the pipette into the cell. In recordings from older animals (P3-P5) the potentials were blocked by 30 $\mu \mathrm{M}$ strychnine and $20 \mu \mathrm{M}$ bicuculline (data not shown). Each trace is the average of 5-20 individual records, and resting potentials in the recordings that are shown varied between -68 and $-85 \mathrm{mV}$.

\section{Results}

\section{Generation and analysis of En1 ${ }^{\text {Cre }}$ knock-in and ROSA26 reporter mice}

A floxed neo-stop-Cre expression cassette was inserted into the first coding exon of En1 (Fig. 1A), using a strategy previously used for restricting lacZ and taulacZ to En1-expressing cells (Hanks et al., 1995; Saueressig et al., 1999). To ensure that Cremediated recombination faithfully reflects the expression pattern of En1 in the developing spinal cord, we crossed $E n 1^{\mathrm{Cre} /+}$ mice with two strains of ROSA26 reporter mice that conditionally express either $\beta$-gal (R26 ${ }^{\text {lac } Z}$; Soriano, 1999) or EGFP (R26 $6^{E G F P}$; Mao et al., 2001). Reporter gene expression in the spinal cord of $\mathrm{EnI}^{\mathrm{Cre} /+} ; \mathrm{R}^{\text {lacZ }}$ and $\mathrm{En1} 1^{\mathrm{Cre} /+} ; R 26^{\text {EGFP }}$ embryos was observed from E10.5 onward. In E11.5 double-heterozygous embryos the patterns of $\beta$-gal activity (Fig. $1 A, C$ ) and EGFP expression (Fig. $1 D-F)$ were indistinguishable from endogenous En1 expression. Moreover, in E11.5 En1 ${ }^{\mathrm{Cre} /+} ; R 26^{E G F P}$ embryos there was a complete colocalization of EGFP and the endogenous En1 protein (Fig. $1 D-F$ ). Expression of both reporters was observed postnatally in $E n 1^{\mathrm{Cre} /+} ; R 26^{E G F P}$ and $E n 1^{\mathrm{Cre} /+} ; R 26^{\text {lacZ }}$ mice, with $\beta$-gal activity being readily detectable as late as 3 months after birth (data not shown).

\section{V1 INs are GABAergic and synapse with motor neurons}

Previous studies showing GAD65 is expressed in newborn $E n 1^{+}$ neurons led us to hypothesize that V1 INs develop as local circuit 

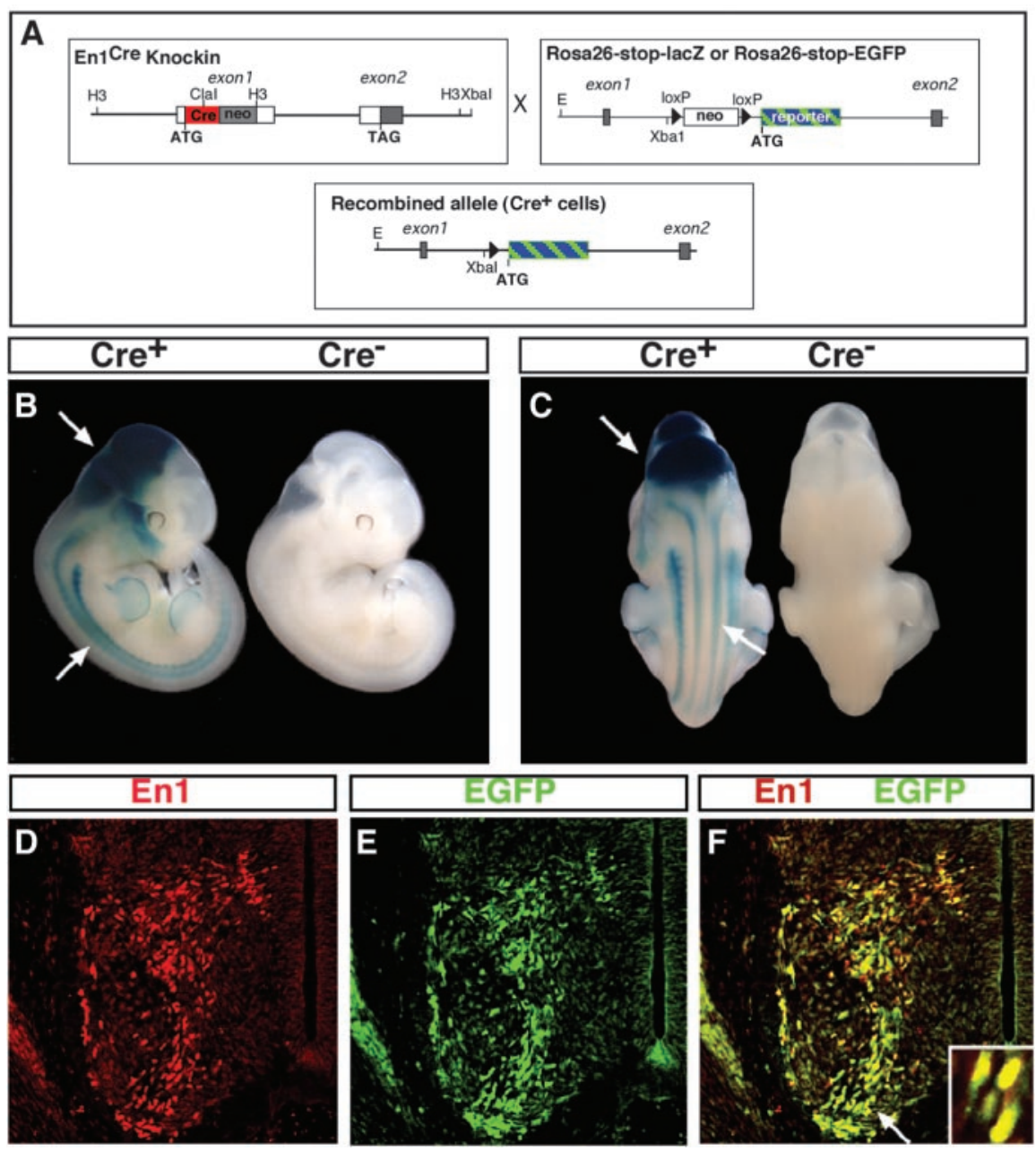

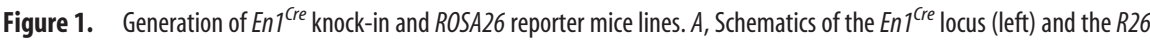
reporter loci (right) are shown in the top boxes. The first coding exon of the $E n 1$ gene contains a Cre PGK-neo-pA cassette resulting in a null mutation. At the ROSA26 locus a loxP-PGKneo-tpA-IoxP (stop) sequence was inserted in the unique Xbal site and prevents transcription of the reporter gene until Cre-mediated recombination occurs (bottom box). B, C, X-gal staining of E11.5 En ${ }^{\mathrm{Cre} /+}$; $R 26^{\text {lacZ/lacZ }}$ and $E n 1^{+/+} ; R 26^{\text {lacZ/lacZ }} . \beta$-Gal is expressed in the spinal cord and in the midbrain (arrows). D-F, Cross sections of E11.5 neural tubes showing complete overlap between EGFP reporter (green) and endogenous En1 immunoreactivity (red) expression in V1 INs. The arrow in Findicates the region enlarged in the inset.

GABAergic interneurons (Saueressig et al., 1999). Consistent with this hypothesis, electrophysiological studies indicate that some embryonic En $1^{+}$neurons in the chick spinal cord form monosynaptic connections with motor neurons, many of which are sensitive to the $\mathrm{GABA}_{\mathrm{A}}$ inhibitor bicuculline (Wenner et al., 2000 ). Because GABA is expressed only weakly at early developmental times, we analyzed the distribution of $\mathrm{GABA}^{+}$neurons at later developmental times to determine whether V1 INs, or a subset thereof, develop as inhibitory interneurons. Widespread GABA expression was seen in the ventral horn of E15.5 En ${ }^{\mathrm{Cre} /+}$; R26 $6^{E G F P}$ embryos (Fig. $2 A$ ), with $>90 \%$ of the $\mathrm{EGFP}^{+} \mathrm{V} 1 \mathrm{INs}$ expressing medium to high levels of GABA (see inset). We also observed a population of $\mathrm{EGFP}^{+} / \mathrm{GABA}^{+}$neurons adjacent to the ventral white matter where Renshaw cells normally are found (Fig. $2 A$, arrow).

Many inhibitory INs in the ventral horn make monosynaptic connections with motor neurons. These interneuron cell types include Ia inhibitory INs, Ib inhibitory INs, and Renshaw cells (Jankowska, 1992, 2001). We therefore asked whether V1-derived neurons synapse directly with motor neurons. To do this, we generated a novel $\mathrm{R} 26$-derived reporter line in which the $\mathrm{N}$ terminus of the axonal growth-associated protein GAP43 is fused to EGFP, thereby allowing for the visualization of $\mathrm{V} 1$ axonal contacts. Analysis of the distribution of $\mathrm{EGFP}^{+}$axonal varicosities with respect to motor neurons in $\mathrm{P} 4$ $\mathrm{En1}^{\mathrm{Cre} /+} ; \mathrm{R} 26^{\text {GAP43-EGFP }}$ mice revealed large numbers of somatic motor neurons decorated with $\mathrm{EGFP}^{+}$axons from V1 INs (Fig. $2 B)$. Moreover, what appear to be $\mathrm{EGFP}^{+}$ terminal varicosities were noted on the soma and proximal dendrites of motor neurons (Fig. 2C) where motor neuron inhibitory synapses are located. Similar EGFP ${ }^{+}$terminal varicosities were found surrounding mature (P18-P20) and adult (3 month) motor neurons (data not shown), indicating that V1 INs provide synaptic input to motor neurons.

The transsynaptic trafficking of TTC fragment fusion proteins and WGA is known to be sensitive to presynaptic neuronal activity (Yoshihara et al., 1999; Miana-Mena et al., 2002). These tracers therefore can be used to reveal the presence of functional synapses between V1 INs and motor neurons. Although WGA also can be transported from postsynaptic dendrites to presynaptic axons, this route of transfer is very inefficient (Miana-Mena et al., 2002). Two complementary approaches were used to assess synaptic contacts between V1 INs and motor neurons: (1) transsynaptic labeling of motor neurons with a floxed WGA reporter mouse (Yoshihara et al., 1999; Y. Yoshihara, unpublished results) and (2) retrograde transsynaptic labeling of V1 INs from defined populations of motor neurons by the use of TTC fusion proteins (Coen et al., 1997). First, mice carrying a conditional floxed WGA reporter line were crossed with En1 $1^{\text {Cre }}$ knock-in mice. After Cremediated excision of the "stop" signal, a truncated form of the WGA protein was transported into axons and dendrites of V1 INs and from there transsynaptically into second-order and in some cases third-order neurons. In examining the spinal cords of $\mathrm{P} 0$ $E n 1^{\mathrm{Cre} /+}$; loxP-stop-loxP-WGA/+ mice, we found that most HB9 ${ }^{+}$motor neurons contained WGA (Fig. $2 D$ ), demonstrating transport of the lectin from V1 INs into motor neurons. WGA labeling also was seen in many other ventral cells (Fig. 2D). However, few, if any, cells in the dorsal horn contained WGA, and there was no WGA expression in the absence of Cre recombination (data not shown). Interestingly, the widespread pattern of WGA staining in the ventral horn mirrored the diffuse arborization of V1 axons in the ventral spinal cord (Fig. $2 \mathrm{~B}$; data not shown), indicating that it is specific to neurons that are postsynaptic to V1 INs. These data raise the possibility that V1 INs synapse with multiple ventral neuron cell types aside from motor neurons.

We then analyzed retrograde transsynaptic translocation of TTC-EGFP from motor neurons into connected interneurons by injecting 100-150 $\mu \mathrm{g}$ of tracer into the hindlimb muscles (gluteus and hamstrings) of $\mathrm{P} 0 \mathrm{En} 1^{\mathrm{Cre} /+} ; \mathrm{R} 26^{\text {lac }}$ pups. At $4 \mathrm{hr}$ after 
intramuscular injection, anti-EGFP antibody stains revealed a network of motor neuron dendrites and somata (Fig. $2 F$, arrow). This staining was quite punctate, reflecting the localization of TTC-EGFP to endosomal compartments. Whereas large numbers of V1 INs were labeled $24 \mathrm{hr}$ after injecting TTC-EGFP (data not shown), we also detected TTC-EGFP in a subset of $\mathrm{lacZ}^{+} \mathrm{V} 1 \mathrm{INs}$ as early as $4 \mathrm{hr}$ after injection (Fig. 2E). V1 INs exhibiting fast TTCEGFP uptake predominantly were positioned close to labeled motor neurons in the Renshaw cell area, suggesting that they may be Renshaw cells. This rapid labeling of putative Renshaw cells may be attributable to the anterograde translocation of TTC-EGFP from motor neurons via collaterals that synapse onto Renshaw cells.

\section{Renshaw cells develop from V1 INs}

To determine whether Renshaw cells arise from V1 INs, we examined the spinal cords of P18 En1 ${ }^{\mathrm{Cre} /+} ; \mathrm{R}_{2} 6^{\text {lac } Z}$ animals, when the mature features of Renshaw cells can be seen readily. After P10 the Renshaw cells show strong calbindin immunoreactivity (Geiman et al., 2000), whereas other ventral horn neurons that express calbindin either are located more dorsally or express calbindin at much lower levels (Fig. 3B). Furthermore, almost all strongly immunolabeled calbindin ${ }^{+}$neurons in ventral lamina VII receive cholinergic inputs onto their dendrites and display large surface gephyrin membrane clusters opposite to inhibitory synapses on their soma and proximal dendrites. This characteristic synaptic organization specifically identifies adult Renshaw cells (Alvarez et al., 1999; Geiman et al., 2002) and is clearly apparent after P10 (Geiman et al., 2000). In $E n 1^{\text {Cre/+}} ; R 26^{\text {lacZ }}$ spinal cords V1-

derived INs expressing lacZ/ $\beta$-gal were restricted mainly to the ventral horn, occupying much of lamina VI, lamina VII, and the ventral-most regions of lamina IX (Fig. $3 A$ ). In sections taken from two P18 animals we counted $94 \pm 2.4$ (mean \pm SEM) lacZ ${ }^{+}$ V1 INs per ventral horn in $40-\mu$ m-thick sections from the L5 segment. These neurons were distributed in an arc around the motor neuron pools, and most were located in the ventral 500 $\mu \mathrm{m}$ of the spinal cord gray matter (Fig. 3C). Almost all of the calbindin ${ }^{+}$neurons located in the Renshaw cell area (ventralmost $200 \mu \mathrm{m}$ of lamina VII and IX) were lacZ $Z^{+}$(Fig. 3A,B). Whereas lac ${ }^{+}$-derived V1 INs were distributed throughout the ventral horn, calbindin ${ }^{+} / \mathrm{lac}^{+}$neurons were positioned predominantly near the ventral white matter where motor axons exit the cord (Fig. 3B,C). We counted $9.9 \pm 0.5$ (per $40 \mu \mathrm{m}$ section) calbindin ${ }^{+} / \mathrm{lacZ}^{+}$neurons in the Renshaw cell region of each ventral horn ( $n=24$ ventral horns), indicating that these putative Renshaw cells constitute $10 \%$ of the V1 IN population.

We then examined gephyrin staining in these calbindin ${ }^{+} /$ lac ${ }^{+}$neurons. V1-derived lac ${ }^{+}$cells outside the Renshaw cell area exhibited punctate gephyrin staining on their soma and den-
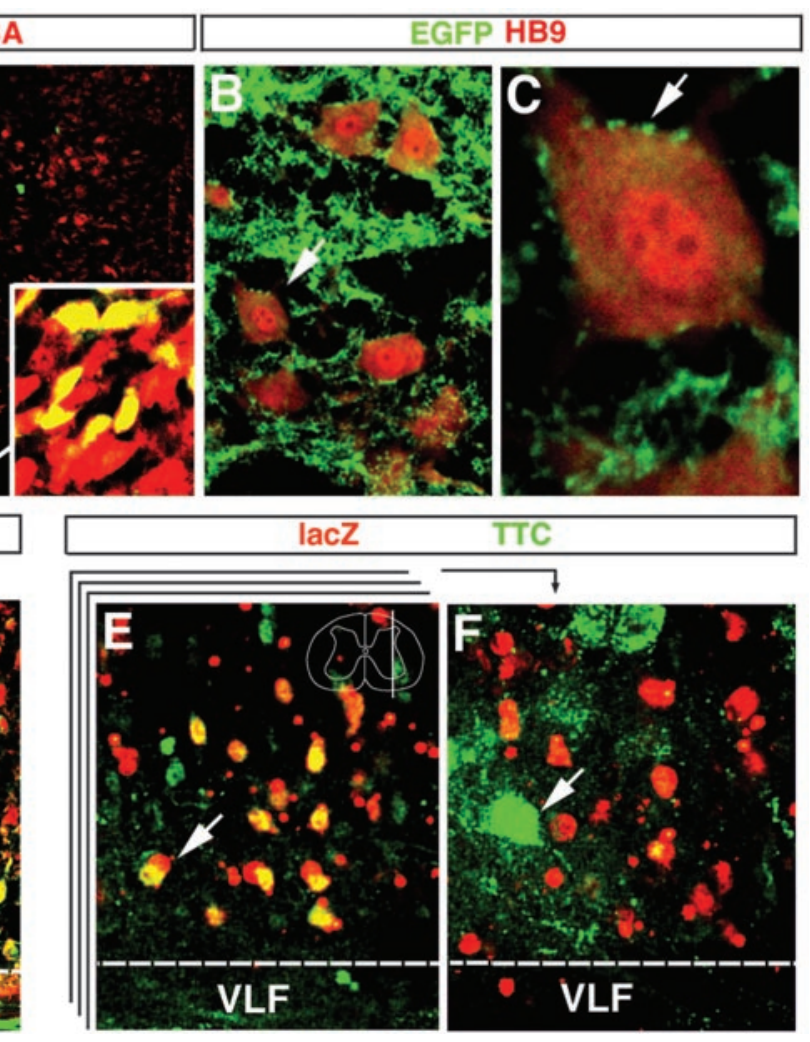

HB9

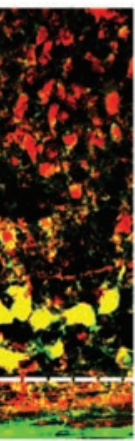

Figure 2. Neurotransmitter phenotype and connectivity of V1 INs. A, Transverse section through the ventral horn of an E15.5 $E n 1^{\text {Cre/+; } R 26^{E G F P}}$ showing V1 INs (green) expressing GABA (red). Dashed line indicates the ventral spinal cord edge. Most of the EGFP V1 cells in the field of view express GABA at moderate levels. High levels of GABA immunoreactivity were detected in cells

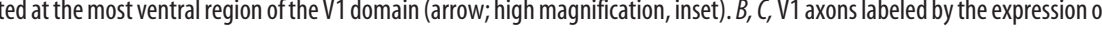
arrow). D, A parasagittal cross section through the spinal cord of a $\mathrm{POEn} 1^{\mathrm{Cre} /+}$;loxP-stop-loxP-WGA animal showing WGA immudashed line marks the white/gray matter border. E, F, Sections showing retrograde transsynaptic TTC-EGFP labeling of neurons in the ventral horn $4 \mathrm{hr}$ after the injection of gluteal and hamstring muscles. The two panels show different confocal planes through

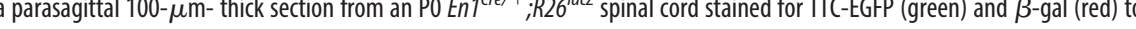
dentify V1 INs. The approximate level of the plane of section is shown in the inset drawing in $E$ that includes the Renshaw cell

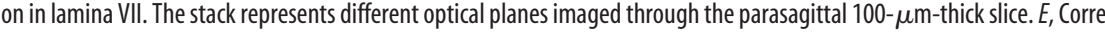
contain TTC-EGFP (green; colocalization, yellow; arrow). $F$, Correspondence to a more lateral optical plane coursing through the adjacent labeled motor pools (green; arrow). Scale bars: $A, B, D, 25 \mu \mathrm{m} ; C, 10 \mu \mathrm{m} ; E, F, 20 \mu \mathrm{m}$.

drites that were small-sized, and they did not express calbindin (Fig. 3D). In contrast, lacZ ${ }^{+} /$calbindin $^{+}$cells within the Renshaw cell area possessed large gephyrin clusters typical of Renshaw cells (Fig. 3E,F). They also expressed the $\alpha 4$ nicotinic AChR subunit (Fig. $3 G$ ) and had $\mathrm{VAChT}^{+}$contacts on their surface (data not shown), thereby demonstrating they have cholinergic synaptic inputs and postsynaptic nicotinic receptors characteristic of Renshaw cells (Dourado et al., 2002). We conclude that these lac ${ }^{+}$and calbindin ${ }^{+}$neurons represent Renshaw cells.

In serial sections taken from four P19 $\mathrm{En}^{\mathrm{Cre} /+} ; \mathrm{R}_{2} 6^{\text {lac } Z}$ animals and immunolabeled with different markers, we counted $8.1 \pm 0.3$ ( $n=42$ ventral horns) "large" gephyrin ${ }^{+} / \mathrm{lacZ}^{+}$cells per ventral horn and $8.0 \pm 0.3(n=57$ ventral horns $)$ calbindin ${ }^{+} /$"large" gephyrin ${ }^{+} / \mathrm{lacZ}^{+}$cells per ventral horn as compared with $9.5 \pm 0.4(n=66$ ventral horns $)$ calbindin ${ }^{+} / \mathrm{lacZ}^{+}$ neurons per ventral horn (Fig. $3 H$ ). The small difference between calbindin ${ }^{+} / \mathrm{lacZ}^{+}$neurons and those containing large gephyrin clusters was statistically significant ( $p<0.05, t$ test), possibly reflecting Renshaw cells that have not yet developed their full complement of large gephyrin clusters. Alternatively, some calbi- 

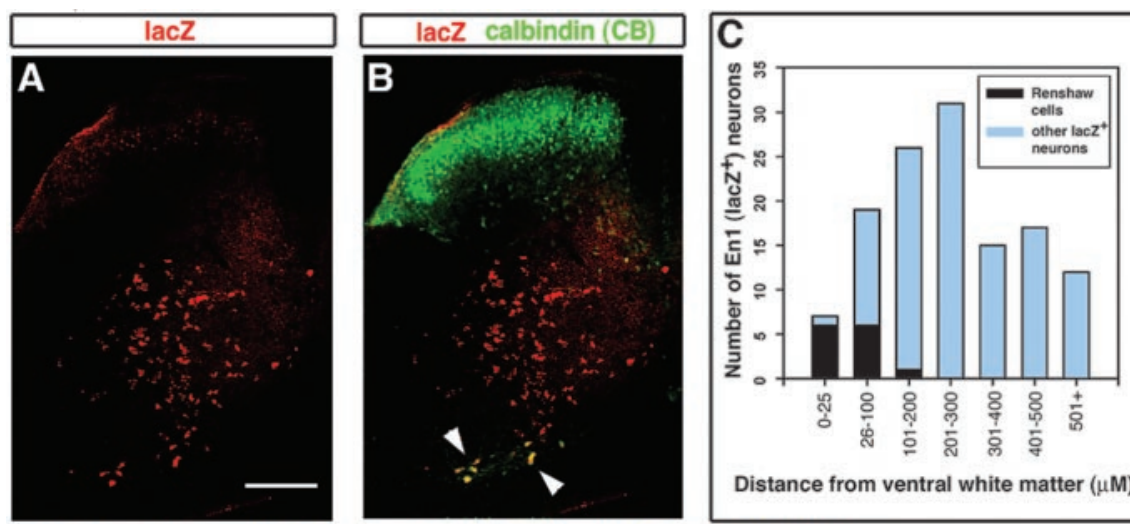

Distance from ventral white matter $(\mu \mathrm{M})$
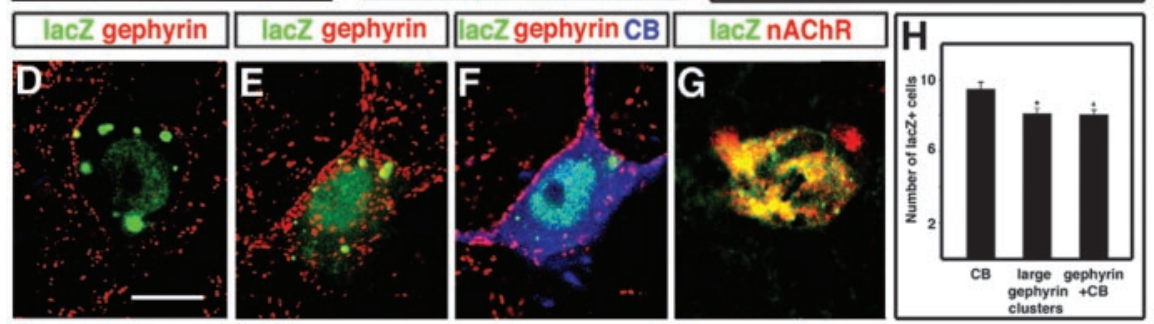

Figure 3. A subpopulation of V1 INs express Renshaw cell-specific markers. V1 INs were identified by expression of lacZ immunoreactivity in $\mathrm{En} 1^{\mathrm{Cre} /+} ; R 26^{\text {lacZ }}$ mice. $A, B$, Low-magnification images of a spinal cord section showing lacZ immunostaining $(A)$ or calbindin $(C B) / l a c Z$ dual color immunofluorescence $(B)$. Renshaw cells are identified as brightly calbindinimmunofluorescent cells in the ventral horn and coexpress lacZ (yellow, arrowheads). C, Distribution of calbindin ${ }^{+}(C B) / l a c Z^{+}$ Renshaw cells and other lac $Z^{+}$neurons in the $D-V$ axis of the ventral horn. Neurons located at different distances from the ventral gray/white matter border are plotted in $100-\mu \mathrm{m}$-distance bins. Neurons in the first $25 \mu \mathrm{m}$ have been separated from the first 100 $\mu \mathrm{m}$ bin to stress the characteristic location along the ventral gray/white matter border of a large number of $\mathrm{CB}^{+} / \mathrm{lacZ}^{+}$Renshaw cells. The histogram shows data from one ventral horn. Similar histograms were obtained in another two ventral horns. $D, E$, Examples of $\mathrm{V} 1 \mathrm{INs}$ (lacZ ${ }^{+}$, green granules) with small $(D)$ or large $(E)$ gephyrin clusters. $F$, lacZ ${ }^{+}$neurons with large gephyrin clusters also express calbindin (blue) and represent Renshaw cells. Each image is a superimposition of three confocal optical planes (0.5 $\mu \mathrm{m} z$-steps). $G$, lacZ ${ }^{+}$neurons in the Renshaw cell area express the $\alpha$ 4NAcR subunit. $H$, Comparison among the average number of lacZ ${ }^{+} \mathrm{V} 1$ INs that express Renshaw cell-like large gephyrin clusters on their surface (number of ventral horns analyzed, $n=42)$, calbindin immunoreactivity $(n=66)$, or the combination of both features $(n=42)$. Counts were done in the ventral 200 $\mu \mathrm{m}$ of the gray matter. The difference in numbers was statistically significant $\left({ }^{*} p<0.05, t\right.$ test). Note that all lacZ ${ }^{+}$cells with large gephyrin clusters were calbindin ${ }^{+}$. Error bars represent SDs. Scale bars: (in A) A, B, $200 \mu \mathrm{m}$; (in D) D-G, $10 \mu \mathrm{m}$. present at E13.5, because injection of two different dextran tracers approximately one segment apart in the lumbar spinal cord enlargement (Fig. 4D) resulted in both fluorescein-dextran ${ }^{+} /$calbindin $^{+}$ (caudally projecting) and rhodaminedextran $^{+} /$calbindin $^{+}$(rostrally projecting) cells. In many instances triple-labeled cells were detected (Fig. 4E, arrow), indicating the presence of Renshaw cells with rostrally and caudally projecting axons. It therefore appears that, as in the cat, Renshaw cells in the mouse spinal cord project both rostrally and caudally, a finding that is consistent with all Renshaw cells arising from V1 INs.

\section{Renshaw cells fail to develop in Pax6 mutant mice}

V1 IN progenitors express the paired homeodomain transcription factor Pax6. En1 is downregulated in Small eye (Sey) mutants that lack Pax6, whereas Evx1 and Chx10, which mark the adjacent V0 and V2 interneuron populations, continue to be expressed (Burrill et al., 1997; Ericson et al., 1997). This has led to the suggestion that Pax 6 may be required selectively for the correct specification of V1 INs or mature interneuron cell types that are derived from V1 INs. We tested whether Pax6 is critical for the development of Renshaw cells by asking whether calbindin ${ }^{+}$cells are still present in the Renshaw cell region of E17.5 homozygous Sey embryos (Fig. 5). This time point was chosen because Sey mutants die at birth, and the combination of cell position and calbindin expression ndin ${ }^{+}$neurons may not be Renshaw cells. Interestingly, 7-8\% of the calbindin neurons in the Renshaw cell area are stained weakly and do not possess large gephyrin clusters, suggesting that they may represent a distinct functional class of interneurons. Nevertheless, $>90 \%$ of the calbindin ${ }^{+}$neurons in the Renshaw cell region displayed a Renshaw cell phenotype and, of these, all were lacZ ${ }^{+}$.

Whereas embryonic V1 INs predominantly extend axons rostrally for one to two segments (Saueressig et al., 1999), Renshaw cell axons in the adult cat project both caudally and rostrally (Fyffe, 1991). This suggests that some Renshaw cells might develop from embryonic neurons that are not V1 INs. We therefore examined whether calbindin ${ }^{+}$cells identified as being putative Renshaw cells possess axons that project both rostrally and caudally in the spinal cord. Renshaw cell projections first were examined in the P4 spinal cord by retrogradely labeling axons and neurons in the lumbar ventral spinal cord with fluoresceinconjugated dextran (Fig. 4; see Materials and Methods). Renshaw cells were identified as those cells showing strong calbindin staining located next to the ventral white matter in the Renshaw cell area. In P4 spinal cords the retrogradely labeled calbindin ${ }^{+}$ "Renshaw cells" were observed both rostral and caudal to the injection site (Fig. $4 A, B$ ), and they possessed axons that extended up to $600 \mu \mathrm{m}$ in a rostral direction and $500 \mu \mathrm{m}$ in a caudal direction (Fig. 4C). These caudally directed axons were also identifies putative Renshaw cells with a high degree of confidence at E17.5. In the lumbar spinal cord (L3-L5) of wild-type embryos (Fig. 5A) we counted $6.9 \pm 0.4\left( \pm\right.$ SEM) calbindin ${ }^{+}$neurons per ventral horn that were located close to the white matter gray matter border ( $n=4 ; 40$ - $\mu$ m-thick sections $)$. Fewer calbindin ${ }^{+}$ Renshaw cells were counted in sections from E17.5 embryos versus P18 animals (compare with Fig. 2), in part because the positional criteria we used for designating calbindin ${ }^{+}$neurons as "Renshaw cells" in the embryonic spinal cord was more conservative. In E17.5 Sey mice a dramatic reduction $(>90 \%)$ in the number of calbindin ${ }^{+}$cells located close to the white matter border was noted (Fig. 5B; $0.6 \pm 0.3$ calbindin $^{+}$cells per $40 \mu \mathrm{m}$ section). Other groups of calbindin ${ }^{+}$interneurons were still present in the Sey mutant spinal cord (Fig. 5B); however, calbindin ${ }^{+}$cells within the Renshaw cell area were lost selectively at all spinal cord levels. These findings suggest that Pax6 is required for the early specification of Renshaw cells. It is, however, possible that in Sey mutants the putative Renshaw cells downregulate calbindin expression or settle outside the Renshaw cell area. The latter possibility seems unlikely, because we never observed calbindin ${ }^{+}$cells at ectopic locations in the Sey mutant spinal cord.

We obtained further evidence for the absence of functional Renshaw cells in Sey mice by electrophysiological recordings of the synaptic input from Renshaw cells to spinal motor neurons. In wild-type mice the stimulation of a ventral root evokes synap- 

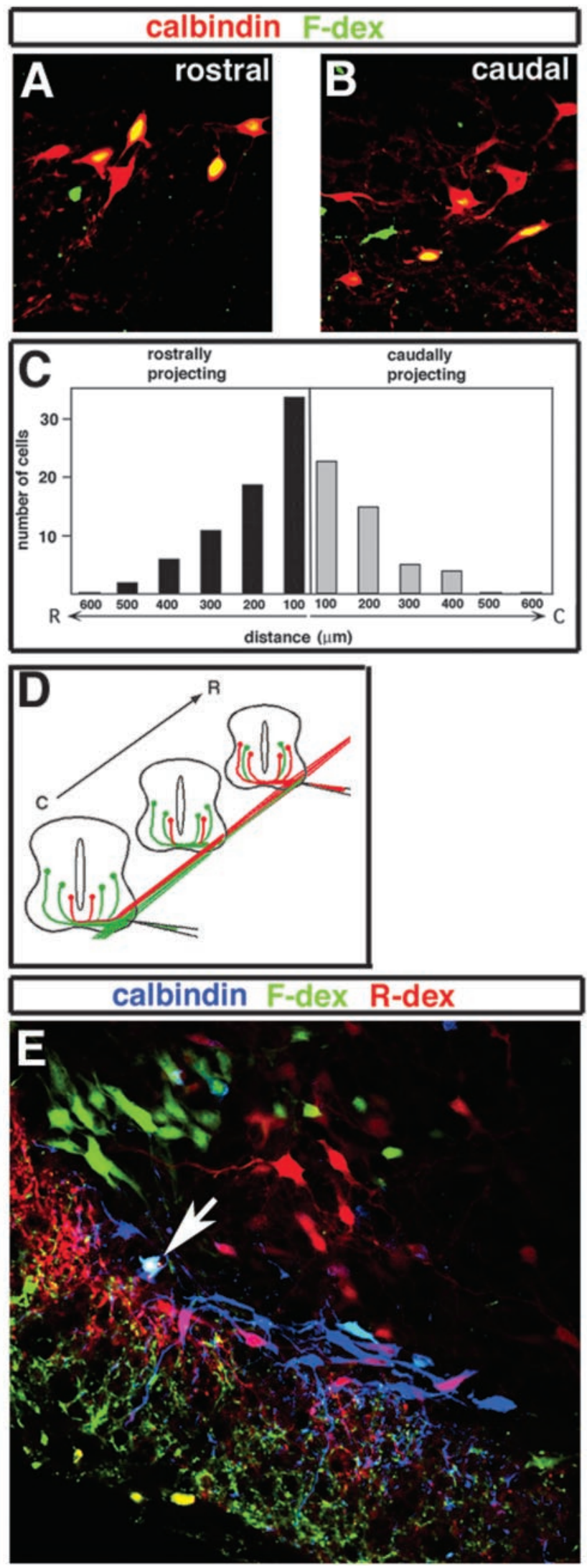

Figure 4. Renshaw cell axon projections. $A-C$, Labeling of calbindin ${ }^{+}$interneurons in the Renshaw cell area of lumbar spinal cord of $\mathrm{P} 4$ animals, using fluorescein-conjugated dextran (F-dex). A, B, Labeled cells are shown in sections both rostral and caudal to the injection. $C$, Counts of the total number of double-labeled cells identified as rostrally projecting (found tic potentials in most motor neurons projecting out the same or adjacent ventral root (Fig. 5D,E, top traces). Although these potentials usually are depolarizing in young animals (see Materials and Methods), they were blocked by a combination of strychnine and bicuculline, indicating they are mediated by glycine and/or GABA (data not shown). These potentials were also sensitive to both curare and mecamylamine (Fig. 5D,E, bottom traces), which block the cholinergic input from motor neuron collaterals to Renshaw cells (Eccles et al., 1954; Dourado and Sargent, 2002). Although synaptic input from Renshaw cells to motor neurons was seen routinely in wild-type E18.5 embryos, both from the same ventral root $(n=5$ of 5$)$ and from adjacent ventral roots ( $n=5$ of 5 ), no such inputs were found in Sey mutant mice from the same litters (Fig. 5F; $n=0$ of 5 for inputs from each of same and adjacent ventral roots). These data further demonstrate the lack of functional Renshaw cell connectivity in Sey mutants. The loss of Renshaw cell connectivity in Sey mice provides further evidence that Renshaw cells are derived exclusively from V1 INs.

The recurrent inhibitory synaptic circuit is altered in En1 ${ }^{\text {Cre/Cre }}$ knock-out mice

The demonstration that En 1 expression is all but absent in Pax6 mutant mice (Burrill et al., 1997; Ericson et al., 1997) led us to ask whether Renshaw cells differentiate correctly in En1 mutant mice. Most En $1^{\mathrm{Cre} / \mathrm{Cre}}$ knock-out mice die approximately at birth. However, a small number of animals survive to adulthood, thus allowing us to look for Renshaw cells and examine their reciprocal connections with motor neurons in adult mice lacking En1. En $1^{\text {Cre/Cre }}$ knock-out mice at P18 showed no differences in the number of calbindin ${ }^{+}$Renshaw cells per ventral horn or in the relative levels of calbindin expression in these cells as compared with control En1 ${ }^{\mathrm{Cre} /+} ; R 26^{\text {lacZ }}$ heterozygotes (Fig. 6A,B,G). This finding shows that $E n 1$ is not necessary for the differentiation or survival of Renshaw cells, nor were any obvious differences seen in the extension of dendritic arbors from these cells, as visualized with calbindin immunoreactivity. Furthermore, the incidence of $\mathrm{VAChT}^{+}$cholinergic contacts on the somata/proximal dendrites of calbindin ${ }^{+}$Renshaw cells was similar in En1 mutant mice when compared with control heterozygotes (Fig. 6C,H). To assess whether these $\mathrm{VAChT}^{+}$terminals are likely to represent functional synapses, we analyzed the translocation of TTC-lacZ from motor neurons to Renshaw cells by using the short labeling times that appear to label selectively the Renshaw cells, but not other interneuron cell types, in the neonatal spinal cord. In P4 En1 mutant and heterozygous animals alike, robust TTC-lacZ labeling of calbindin ${ }^{+}$Renshaw cells was noted (Fig. 6E,F). In summary, these analyses did not detect significant changes in the connections made by motor axon collaterals onto Renshaw cells.

In contrast to the "normal" innervation of Renshaw cells by motor neurons, we noted far fewer calbindin ${ }^{+}$contacts onto motor neurons in the En1 $1^{\mathrm{Cre} / \mathrm{Cre}}$ mutant mice (Fig. $7 A-D$ ), indicating a reduction in recurrent inhibitory synapses. On average, $31.8 \pm 4( \pm$ SEM $)$ calbindin ${ }^{+}$contacts were present on recon-

$\leftarrow$

caudal to the cut site) or caudally projecting (found rostrally to the cut site) from three separate experiments suggest that calbindin ${ }^{+}$neurons in the Renshaw cell area extend their arbor both caudally and rostrally. D, Labeling of an E13.5 embryo, with F-dex (rostral site) and rhodamineconjugated dextran (R-dex; caudal site). This experimental design allows for visualization of rostrally (red) and caudally (green) projecting neurons in sections between both injection sites. $E$, Transverse section of the ipsilateral E13.5 hemi-cord midway between the two injection sites, showing rostrally projecting calbindin ${ }^{+}$Renshaw cells (magenta), caudally projecting calbindin ${ }^{+}$Renshaw cells (light blue), and a bifurcating calbindin ${ }^{+}$Renshaw cell (white; arrow). 

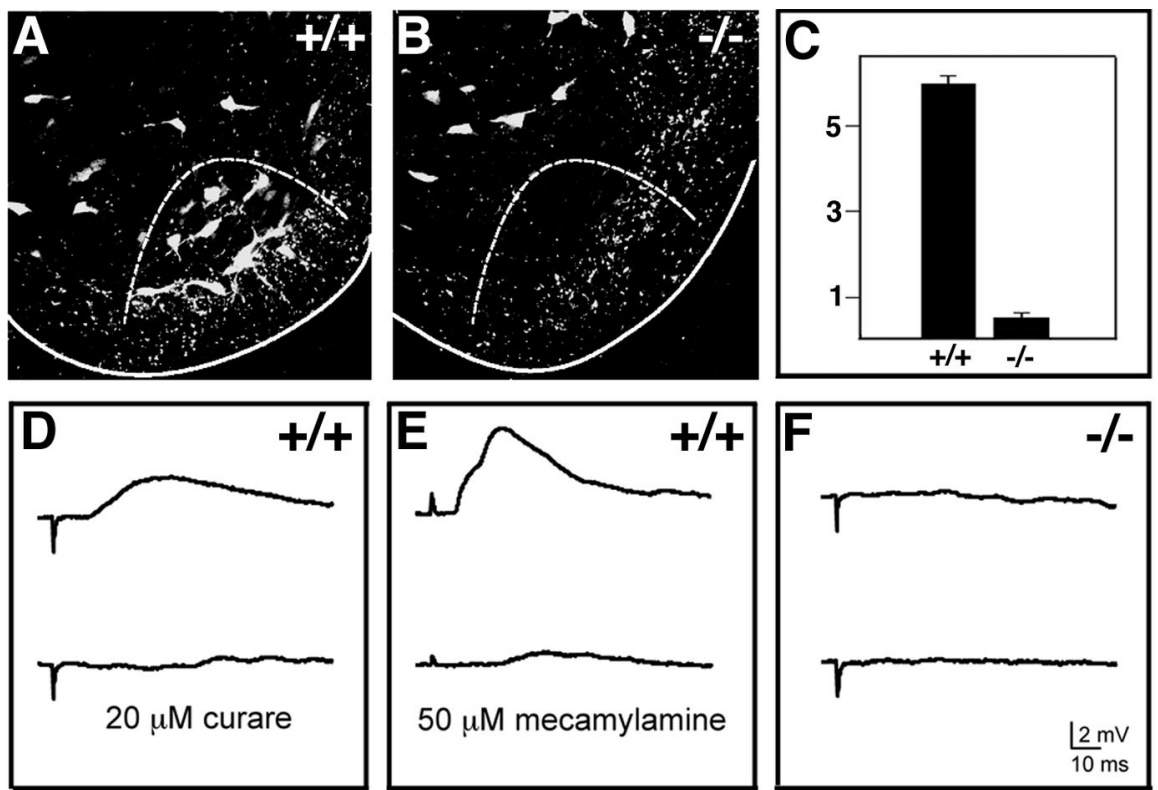

Figure 5. Pax6 is essential for the specification of "Renshaw cells." $A, B$, Calbindin expression in the ventral horn of E17.5 wild-type $(+/+)$ and $\operatorname{Sey}(-/-)$ littermates. The dashed line indicates the Renshaw cell area. The continuous line marks the edge of the spinal cord. C, Calbindin ${ }^{+}$cells in the Renshaw cell region were counted in lumbar sections $(n=96)$ from four embryos. Histogram bars indicate the average number of cells found per section ( $40 \mu \mathrm{m}$ thick). Error bars represent SDs. Scale bar, $50 \mu \mathrm{m} . D-F$, Synaptic input from Renshaw cells to spinal motor neurons in E18.5 wild-type $(+/+)$ and Sey mutant $(-/-)$ mice. In each recording the motor neurons were identified by antidromic activation of the $\mathrm{L} 5$ ventral root, and Renshaw cells were activated by stimulation of motor axons in the L4 ventral root. Glutamatergic inputs to motor neurons that were present in wild-type and Sey mice were blocked with AP5 and CNQX (present for all traces; see Materials and Methods). The potentials in wild-type mice were blocked by both curare $(3 \mathrm{~min})$ and mecamylamine $(9 \mathrm{~min})$, each of which blocks cholinergic input to Renshaw cells $\left(D, E\right.$, bottom traces). No synaptic potentials were evoked by ventral root stimulation in Sey ${ }^{-1-}$ mice $(F)$, indicating that Renshaw cell inputs to motor neurons are absent.

structions of control motor neuron somata $(n=10)$ labeled with antibodies against ChAT as compared with $15.2 \pm 4$ ( \pm SEM) for motor neurons in mutant mice. In examining single optical cross sections through these motor neurons, we estimated an average of $6.2 \pm 1$ contacts per $100 \mu \mathrm{m}$ of linear membrane for control motor neuron sections as compared with $3.1 \pm 0.5$ calbindin ${ }^{+}$ terminals per $100 \mu \mathrm{m}$ of linear membrane in the En1 mutant, a reduction of $50.4 \%$ (Fig. $7 F$ ).

We confirmed that these calbindin ${ }^{+}$contacts arise from V1derived Renshaw cells by showing that in En1 ${ }^{\text {Cre }} ; R 26^{\text {GAP43-EGFP }}$ mice EGFP is coexpressed with calbindin in these contacts onto motor neurons. EGFP immunoreactivity was observed in $91 \%$ of the calbindin ${ }^{+}$varicosities surrounding motor neurons, demonstrating that calbindin ${ }^{+}$contacts on motor neurons are derived primarily from V1 Ins, and they are therefore Renshaw cell axons (data not shown). We conclude that most calbindin ${ }^{+}$terminals on motor neuron somata arise from Renshaw cell axonal arborizations.

We then undertook a rigorous quantification of Renshaw cell to motor neuron synapses by sampling motor neurons at the center of lamina IX in L4, approximately corresponding to the location of the gastrocnemius motor neuron pool. This approach was taken because of the variation in Renshaw cell synapses/calbindin ${ }^{+}$contacts on motor neuron somata in motor neuron pools at different dorsoventral locations, which is known to correlate with differences in the amount of recurrent inhibition that distinct motor pools receive (Hultborn et al., 1971, 1988).

To ensure these calbindin ${ }^{+}$contacts represented synaptic sites, we labeled sections for calbindin and gephyrin, a key component of the postsynaptic scaffold of inhibitory synapses. The large majority $(84.1 \% ; n=85)$ of calbindin ${ }^{+}$terminals in contact with motor neuron somata was associated with postsynaptic gephyrin clusters, indicating that these sites are likely to contain inhibitory GABA and/or glycine receptors (Fig. $7 C, D)$. Often individual calbindin ${ }^{+}$boutons were opposed to several gephyrin clusters, in agreement with previous studies indicating that individual inhibitory synaptic boutons on motor neurons contain several independent synaptic complexes (Alvarez et al., 1997). Interestingly, most of the residual calbindin ${ }^{+}$terminals in the En1 mutant were associated with postsynaptic gephyrin clusters (72.3 \pm $7.0 \%$ ), suggesting that they constitute functional inhibitory synapses. Although there were fewer Renshaw cell-derived calbindin ${ }^{+}$contacts onto mutant motor neurons, the total number of gephyrin ${ }^{+}$ patches was unchanged $(64.4 \pm 3.9$ and $61.0 \pm 2.3$ gephyrin patches per $100 \mu \mathrm{m}$ of linear membrane for mutant and normal motor neurons, respectively; Fig. 7E). Thus it appears that, whereas inhibitory inputs from Renshaw cells onto En1 mutant motor neurons are reduced by $50 \%$, the overall number of gephyrincontaining inhibitory synapses in these motor neurons is normal. This suggests that increased inhibitory inputs from other IN cell types may compensate for the loss of recurrent inhibitory synapses.

\section{Discussion}

Classical studies in the mammalian spinal cord over the past 50 years have provided a wealth of information regarding the physiology of interneurons that contribute to the reflex pathways controlling locomotion (Burke, 1998; Jankowska, 2001). Indeed, the first mammalian interneuron cell type to be identified functionally via electrophysiological techniques was the Renshaw cell that mediates recurrent inhibition of motor neurons (Renshaw, 1946; Eccles et al., 1954). Although much has been learned about the physiology of Renshaw cells, their developmental origin has been difficult to determine. As a result, very little is known of the molecular mechanisms that control the development of Renshaw cells and the locomotor circuits to which they contribute. This study shows that all Renshaw cells are derived from the V1 population of INs that transiently express En1, thereby establishing a direct link between a class of embryonic interneuron and a functionally defined cell type in the adult spinal cord.

V1 INs are one of four early interneuron subtypes that arise in the ventral neural tube (Jessell, 2000; Goulding et al., 2002). In addition to their unique patterns of gene expression, these four interneuron subtypes exhibit characteristic morphological features, suggesting that they represent four early neuronal metatypes, each of which generates multiple neuronal cell types that share some common features. V1 INs, for instance, are inhibitory and their axons project locally, making monosynaptic connections with motor neurons (Saueressig et al., 1999; Wenner et al., 2000; this study). We propose that neurons arising from the V1 IN metatype develop as local circuit inhibitory interneurons that 


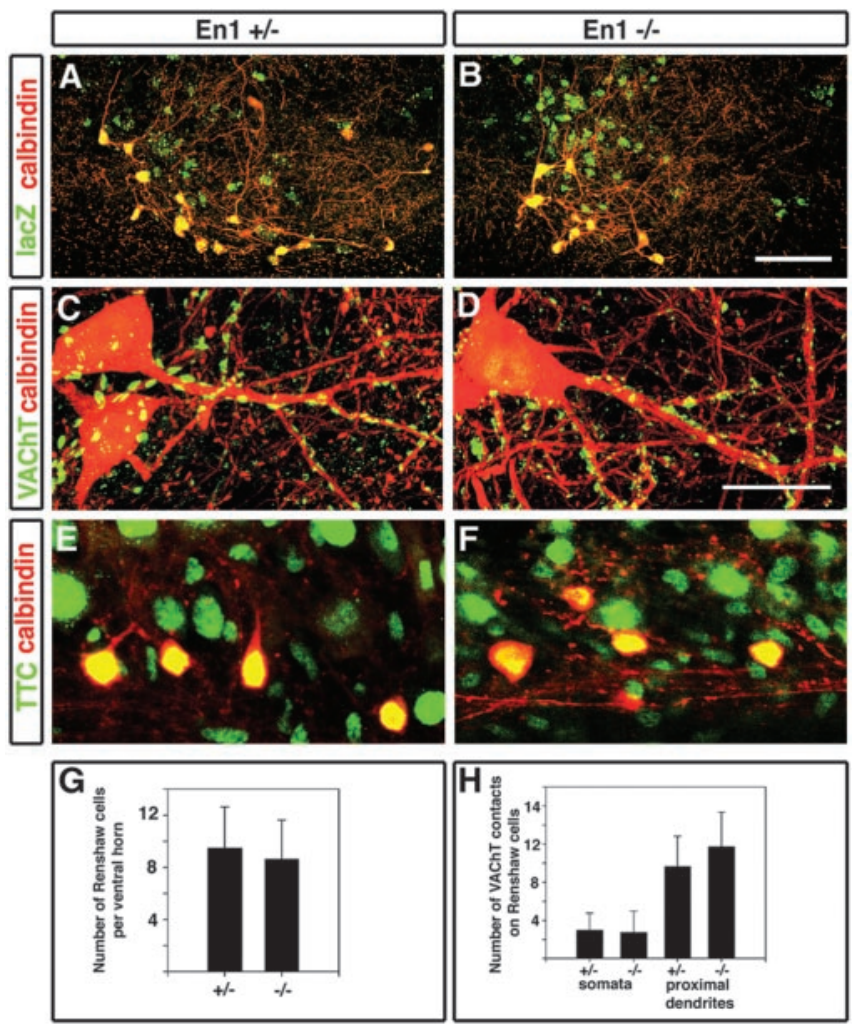

Figure 6. Renshaw cell development and motor neuron to Renshaw cell connections are not altered in $E n 1$ mutant mice. $A, B$, Two ventral horns of a P18 heterozygote $\left(A ; E n 1^{\text {Cre/+ }} ; R 26^{\text {lac }}\right)$ and an $E n 1$ knock-in mouse $\left(B ; E n 1^{\text {(re/(ree; }}, R 26^{\text {lacZ }}\right)$ dual-immunolabeled for calbindin (red) and lacZ (green). Many calbindin-IR and lacZ-IR $\left(\mathrm{CB}^{+} / \mathrm{lacZ}^{+}\right)$Renshaw cells are found in both ventral horns. Neuronal somata and dendrites were not different in both animals. C, D, VAChTimmunoreactive contacts (green) on the dendrites of calbindin- $I R\left(C B^{+}\right)$Renshaw cells (red) in the heterozygote and the $E n 1$ knockin mice $(D)$. These images were obtained from the superimposition of 35 and 53 confocal optical planes $(0.5 \mu \mathrm{m} z$-steps) in $($ and $D$, respectively. $E, F$, Retrograde labeling of Renshaw cells via TTC-lacZ transsynaptic tracer. TTC-lacZ was injected to the gluteal and hamstring muscle groups of $\mathrm{P} 4$ heterozygote $(E)$ and $E n 1$ knock-in mice $(F)$ littermates. In longitudinal sections of the lumbar spinal cord numerous calbindin ${ }^{+}$cells located close to the white/gray matter border were labeled in both heterozygous $(E)$ and $E n 1$ mutant $(F)$ animals. $G$, Average number of calbindin ${ }^{+}\left(\mathrm{CB}^{+}\right) / / \mathrm{lac} Z^{+}$cells per ventral horn section of heterozygote (number of ventral horns analyzed, $n=48$ ) or $E n 1$ mutant mice $(n=$ 66). Both animals contained similar numbers of cells ( $p>0.05, t$ test). $H$, Average number of VAChT-IR contacts on the somata and dendrites of calbindin ${ }^{+}$Renshaw cells in normal heterozygote and En 1 knock-in mice. Eight and four fully reconstructed Renshaw cells somata were

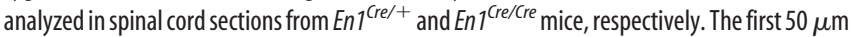
of dendritic length from the soma was reconstructed in nine and four dendrites from $E n 7^{\text {(re/ }+}$ and $E n 1^{\text {Cre/Cre }}$ Renshaw cells, respectively. Error bars represent SDs. Scale bars: (in $\left.B\right) A, B, 100$ $\mu \mathrm{m}$; (in D) C, D, $20 \mu \mathrm{m}$

synapse with motor neurons, a class of cells that would include Renshaw cells. Interestingly, only $10 \%$ of the $E n 1^{+}$V1 INs in the mouse spinal cord differentiate into Renshaw cells, suggesting that V1 INs generate multiple cell types. Further evidence for functional diversity within the V1 IN population comes from electrophysiological analyses of En $1^{+}$neurons in the embryonic chick spinal cord (Wenner et al., 2000). In view of the characteristic phenotype of V1 INs, it is likely that Ia and Ib inhibitory interneurons also arise from the $\mathrm{V} 1$ population.

The observation that the V1 INs generate more than one cell type argues that early postmitotic neurons in the spinal cord undergo further rounds of specialization to generate the many mature interneuron cell types present in the adult. It is unclear, however, at what developmental time these functionally distinct cell types emerge. Whereas V2 INs can be subdivided into two
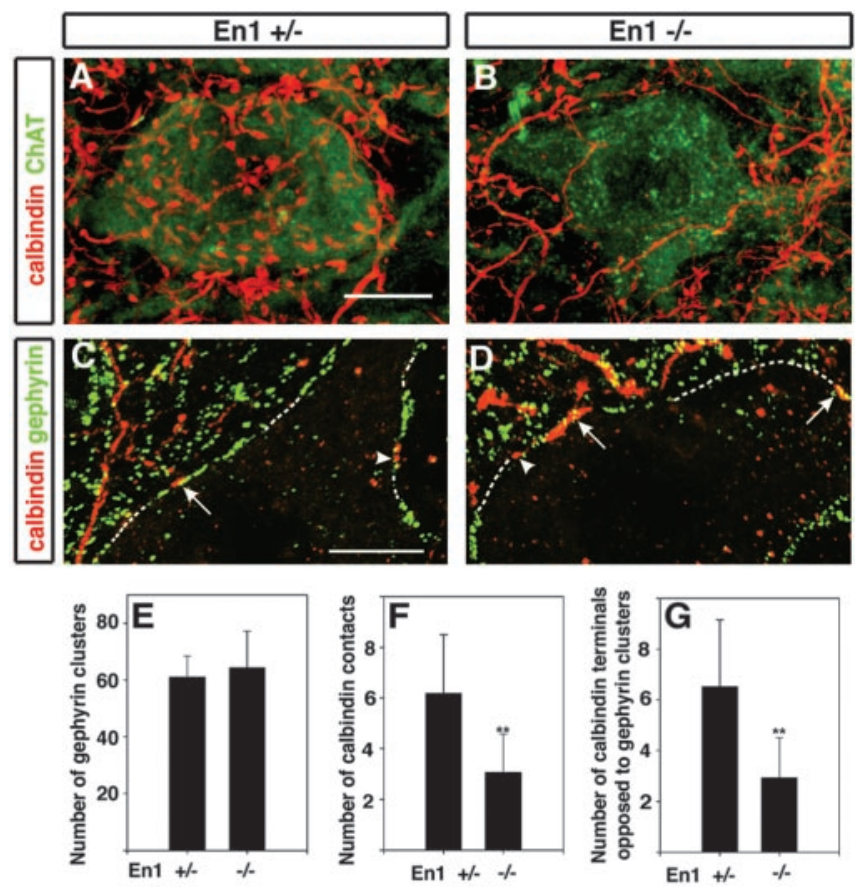

Figure 7. The number of calbindin-IR varicosities in front of postsynaptic motor neuron gephyrin-IR clusters is reduced in the En1 knock-in mouse. $A, B$, Dual immunolabeling for calbindin (red) and choline acetyltransferase (ChAT; green) to label underlying motor neurons in

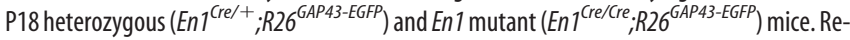
duced numbers of calbindin ${ }^{+}$varicosities around motor neurons were observed consistently in $E n 1^{C r e / C r e}$ knock-in mice $(B)$ as compared with heterozygote littermates $(A)$. The image in $A$ represents a two-dimensional projection of the calbindin ${ }^{+}$plexus around this neuron reconstructed from 31 confocal optical planes. The image in $B$ represents 41 confocal optical sections (z-steps, $0.5 \mu \mathrm{m}$ ).C, D, Dual immunolabeling for calbindin (red) and gephyrin (green) around a motor neuron (dotted line) in a P18 En1 heterozygote ( $C$ and P18 En1 mutant mouse $(D)$. Each image is a single optical plane. Arrows indicate examples of calbindin-IR varicosities opposed to postsynaptic gephyrin clusters. Arrowheads indicate varicosities that were not opposed by gephyrin-IR clusters. $E$, No difference is shown in the average number of gephyrin clusters per $100 \mu \mathrm{m}$ of surface linear membrane in neurons from normal and mutant animals. $F$, Shown is a reduction in calbindin-IR contacts per $100 \mu \mathrm{m}$ of linear membrane in En1 knock-in motor neurons as compared with those from a heterozygote littermate. $G, A$ similar reduction was observed when only calbindin-IR terminals opposed to gephyrin were counted. Usually, motor neuron surfaces are outlined easily by gephyrin-immunoreactive patches because of their high linear density. To obtain surface coverage estimates, we sampled 10 motor neurons from each type of animal via three optical sections separated by $z$-steps of $3 \mu \mathrm{m}$ to ensure that the same terminals were not counted twice. ${ }^{* *}$ Statistical significance ( $p<0.01, t$ test). Error bars represent SDs. Scale bars, $10 \mu \mathrm{m}$

subtypes soon after they are born (Kuranaratne et al., 2002), postmitotic V1 INs appear to be genetically and morphologically homogeneous (Saueressig et al., 1999; M. Goulding, unpublished results), suggesting that V1 IN diversification may be a late event.

Our findings bear on the important issue of whether specific populations of embryonic interneurons in the spinal cord give rise to distinct functional cell types in the adult. Although this is likely to be the case a priori, it has yet to be demonstrated. To the contrary, characterization of the En $1^{+}$population in the E8 chick spinal cord with whole-cell recordings revealed no unique patterns of connectivity (Wenner et al., 2000). Moreover, although V1 INs express markers of inhibitory neurons, other non-V1 inhibitory neurons are present in the ventral horn (Fig. 2A). These and other observations have led to the suggestion that functional interneuron cells types such as Renshaw cells may develop from more than one class of embryonic interneuron (Sharma and Peng, 2001). Three findings in this study argue that 
all Renshaw cells develop from a single embryonic cell type, V1 INs. First, lineage tracing studies show that all neurons exhibiting a mature Renshaw cell phenotype in the postnatal spinal cord derive from V1 INs. Second, virtually all calbindin-expressing Renshaw cells are missing in Pax6 mutant mice that exhibit a selective loss of V1 INs. Finally, recurrent synaptic potentials induced by antidromic stimulation of motor neurons are completely absent from $\operatorname{Pax} 6$ mutant embryos. These findings are the first to provide evidence that functional interneuron cell types in the adult spinal cord arise from distinct populations of embryonic neurons.

Recent studies have highlighted the role that transcription factors play in the early development of embryonic interneurons (Briscoe et al., 2000; Jessell, 2000); however, their function in configuring interneuronal circuits in the adult spinal cord has not been addressed. By defining the embryonic origin of Renshaw cells and coupling this information with well established criteria for identifying Renshaw cells, we have begun to analyze the transcriptional program that regulates the development of Renshaw cells and their interconnections with motor neurons. Putative Renshaw cells are missing in Pax6 mutant mice, demonstrating that Pax6 plays an important early role in the development of this class of neuron. It remains unclear, however, whether the loss of Renshaw cells in Sey embryos represents a specific requirement for Pax6 in developing Renshaw cells or whether Pax6 functions as a general determinant of V1 identity. A number of observations point to the latter possibility. First, GAD65 expression is reduced dramatically at E10.5 in the Sey mutant spinal cord, suggesting a widespread loss of ventral GABAergic interneurons. Second, Pax6 mutant mice exhibit a selective loss of ipsilaterally projecting segmental interneurons in the ventral spinal cord at E12-E13, and these segmental interneurons are primarily V1 INs (J. Glover and M. Goulding, unpublished results).

Although Pax6 is expressed transiently in many ventral progenitor populations, including motor neuron precursors (Ericson et al., 1997), motor neurons are generated in near-normal numbers in the Sey mutant spinal cord (Burrill et al., 1997; Osumi et al., 1997). Furthermore, we have not detected changes in the organization of motor neurons at lumbar levels. These, and other findings, argue that defects in motor neuron development are unlikely to cause the loss of Renshaw cells in $\mathrm{Pax}^{-}$mice. Instead, we favor the idea that Pax6 is required cell autonomously for the proper development of V1 INs and Renshaw cells.

In establishing connections with other neurons, not only is it necessary for neurons to target their synaptic partners correctly, it is also important to form the appropriate number of synapses with them. With respect to recurrent inhibition, differences in the levels of reciprocal innervation between motor neurons and Renshaw cells are an important feature of this circuit (Burke, 1998). Fast-type motor neurons that strongly innervate Renshaw cells receive the lowest level of recurrent inhibition, whereas the reverse is true for slow-type motor neurons (Friedman et al., 1981; Hultborn et al., 1988). The molecular determinants that control the specificity and number of Renshaw cell connections on individual motor neuron pools are unknown. Here we show that the loss of $E n 1$ results in a dramatic reduction in the number of Renshaw cell to motor neuron synaptic contacts (Fig. 7). However, Renshaw cell innervation by motor neuron axon collaterals appears to be unchanged, and TTC-EGFP rapidly is transferred transsynaptically from motor neurons to Renshaw cells, indicating that these recurrent synapses are functional (Fig. 6).

The cellular and molecular mechanisms that underlie the reduced level of recurrent inhibition in En1 mutant mice remain to be determined. Whereas En1 mutant embryos exhibit changes in the fasciculation and pathfinding of V1 axons (Saueressig et al., 1999), similar numbers of Renshaw cell axons and collaterals are observed in the ventral funiculus and around motor neurons in normal and En1 mutant mice. It therefore appears that Renshaw cell axons do target motor neuron pools in mutant En1 mice but form fewer mature synapses with motor neurons. Recent studies have revealed that ephrin-dependent signaling between axons and dendrites regulates dendritic spine morphogenesis (Penzes et al., 2003). This, and other studies showing that the Ephrin proteins regulate synaptic plasticity and NMDA receptor clustering (Dalva et al., 2000; Grunwald et al., 2001), suggests this signaling pathway may coordinate synapse formation during development. In this respect it is interesting to note that En1 activity regulates ephrin gene expression in the chick tectum, thereby altering the topographic targeting of retinal axons (Friedman and O'Leary, 1996; Logan et al., 1996). Furthermore, in Drosophila, the expression of synaptic recognition molecules is modulated by engrailed, the fly homolog of En1 (Marie et al., 2002). Interestingly, the recurrent synapses that do form on motor neurons in the En1 mutant mice appear to be functional, because the calbindin ${ }^{+}$terminals are presynaptic to gephyrin-containing clusters, which are known to be formed and stabilized by activitydependent mechanisms (Kirsch and Betz, 1998; Levi et al., 1999).

This study bridges the divide between molecularly delineated cell types in the embryonic spinal cord and functional cell types in the adult that are defined by their physiology/connectivity. In so doing, it provides a clear example of a strict lineage relationship between a molecularly defined embryonic interneuron class and a functional interneuron cell type in the adult spinal cord. By defining the relationship between V1 INs and Renshaw cells, it is now possible to elucidate the cellular and molecular events that regulate Renshaw cell differentiation and connectivity. Furthermore, genetic strategies now can be exploited to manipulate Renshaw cells selectively in the adult spinal cord, thus enabling an assessment of their function in behaviors such as locomotion.

\section{References}

Alvarez FJ, Dewey DE, Harrington DA, Fyffe REW (1997) Cell-type specific organization of glycine receptor clusters in the mammalian spinal cord. J Comp Neurol 379:150-170.

Alvarez FJ, Dewey DE, McMillin P, Fyffe REW (1999) Distribution of cholinergic contacts on Renshaw cells in the rat spinal cord: a light microscopic study. J Physiol (Lond) 515:787-797.

Arber S, Ladle DR, Lin JH, Frank E, Jessell TM (2000) ETS gene Er81 controls the formation of functional connections between group Ia sensory afferents and motor neurons. Cell 101:485-498.

Arvidsson U, Ulfhake B, Cullheim S, Ramirez V, Shupliakov O, Hokfelt T (1992) Distribution of calbindin D28k-like immunoreactivity (LI) in the monkey ventral horn: do Renshaw cells contain calbindin D28k-LI? J Neurosci 12:718-728.

Briscoe J, Pierani A, Jessell TM, Ericson J (2000) A homeodomain protein code specifies progenitor cell identity and neuronal fate in the ventral neural tube. Cell 101:435-445.

Burke RE (1998) The synaptic organization of the brain (Shephard GM, ed), pp 77-120. New York: Oxford UP.

Burrill JD, Moran L, Goulding M, Saueressig H (1997) PAX2 is expressed in multiple spinal cord interneurons, including a population of $E n 1^{+}$interneurons that require PAX6 for their development. Development 124:4493-4503.

Coen L, Osta R, Maury M, Brulet P (1997) Construction of hybrid proteins that migrate retrogradely and transynaptically into the central nervous system. Proc Natl Acad Sci USA 94:9400-9405.

Cullheim S, Kellerth JO (1982) Two kinds of recurrent inhibition of cat spinal $\alpha$-motoneurones as differentiated pharmacologically. J Physiol (Lond) 312:209-224

Dalva MB, Takasu MA, Lin MZ, Shamah SM, Hu L, Gale NW, Greenberg ME 
(2000) EphB receptors interact with NMDA receptors and regulate synapse formation. Cell 103:945-956.

Dourado M, Sargent PB (2002) Properties of nicotinic receptors underlying Renshaw cell excitation by $\alpha$-motor neurons in neonatal rat spinal cord. J Neurophysiol 87:3117-3125.

Eccles JC, Fatt P, Koketsu K (1954) Cholinergic and inhibitory synapses in a path from motor-axon collaterals to motorneurones. J Physiol (Lond) 126:524-562.

Ericson J, Rashbass P, Schedl A, Brenner-Morton S, Kawakami A, van Heyningen V, Jessell TM, Briscoe J (1997) Pax6 controls progenitor cell identity and neuronal fate in response to graded Shh signaling. Cell 90:169-180.

Friedman GC, O’Leary DDM (1996) Retroviral misexpression of engrailed genes in the chick optic tectum perturbs the topographic targeting of retinal axons. J Neurosci 16:5498-5509.

Friedman WA, Sypert GW, Munson JB, Fleshman JW (1981) Recurrent inhibition in type-identified motoneurons. J Neurophysiol 46:1349-1359.

Fyffe REW (1991) Spatial distribution of recurrent inhibitory synapses on spinal motoneurons in the cat. J Neurophysiol 65:1134-1149.

Geiman EJ, Knox MC, Alvarez FJ (2000) Postnatal maturation of gephyrin/ glycine receptor clusters on developing Renshaw cells. J Comp Neurol 426:130-142.

Geiman EJ, Zheng W, Fritschy JM, Alvarez FJ (2002) Glycine and GABA receptor subunits on Renshaw cells: relationship with presynaptic neurotransmitters and postsynaptic gephyrin clusters. J Comp Neurol 444:275-289.

Glover JC (1995) Retrograde and anterograde axonal tracing with fluorescent dextrans in the embryonic nervous system. Neurosci Protocols 30:1-13.

Goulding M, Lanuza G, Sapir T, Narayan S (2002) The formation of sensorimotor circuits. Curr Opin Neurobiol 12:508-515.

Gross MK, Dottori M, Goulding M (2002) Lbxl specifies somatosensory association interneurons in the dorsal spinal cord. Neuron 34:535-549.

Grunwald IC, Korte M, Wolfer D, Wilkinson GA, Unsicker K, Lipp HP, Bonhoeffer T, Klein R (2001) Kinase-independent requirement of EphB2 receptors in hippocampal synaptic plasticity. Neuron 32:1027-1040.

Hanks M, Wurst W, Anson-Cartwright L, Auerbach AB, Joyner AL (1995) Rescue of the En-1 mutant phenotype by replacement of En-1 with En-2. Science 269:679-682.

Hultborn H, Jankowska E, Lindstrom S (1971) Recurrent inhibition from motor axon collaterals of transmission in the Ia inhibitory pathway to motoneurones. J Physiol (Lond) 215:591-612.

Hultborn H, Lipski J, Mackel R, Wigstrom H (1988) Distribution of recurrent inhibition within a motor nucleus: contribution from slow and fast motor units to the excitation of Renshaw cells. Acta Physiol Scand 134:347-361.

Jankowska E (1992) Interneuronal relay in spinal pathways from proprioceptors. Prog Neurobiol 38:335-378.

Jankowska E (2001) Spinal interneuronal systems: identification, multifunctional character and reconfigurations in mammals. J Physiol (Lond) 533:31-40.

Jessell TM (2000) Neuronal specification in the spinal cord: inductive signals and transcriptional codes. Nat Rev Genet 1:20-29.

Joyner AL (1993) Gene targeting: a practical approach. New York: Oxford UP.

Kirsch J, Betz H (1998) Glycine-receptor activation is required for receptor clustering in spinal neurons. Nature 392:717-720.
Kuranaratne A, Hargrave M, Poh A, Yamada T (2002) GATA proteins identify a novel ventral interneuron subclass in the developing chick spinal cord. Dev Biol 249:30-43.

Levi S, Chesnoy-Marchais D, Sieghart W, Triller A (1999) Synaptic control of glycine and $\mathrm{GABA}_{\mathrm{A}}$ receptors and gephyrin expression in cultured motor neurons. J Neurosci 19:7434-7449.

Logan C, Wizenmann A, Drescher U, Monshau B, Bonhoeffer F, Lumsden A (1996) Rostral optic tectum acquires caudal characteristics following ectopic Engrailed expression. Curr Biol 6:1006-1014.

Mao X, Fujiwara Y, Chapdelaine A, Yang H, Orkin SH (2001) Activation of EGFP expression by Cre-mediated excision in a new ROSA26 reporter mouse strain. Blood 97:324-326.

Marie B, Cruz-Orengo L, Blagburn JM (2002) Persistent engrailed expression is required to determine sensory axon trajectory, branching, and target choice. J Neurosci 22:832-841.

Matise MP, Joyner AL (1997) Expression patterns of developmental control genes in normal and Engrailed-1 mutant mouse spinal cord reveal early diversity in developing interneurons. J Neurosci 17:7805-7816.

Mears SC, Frank E (1997) Formation of specific monosynaptic connections between muscle spindle afferents and motor neurons in the mouse. J Neurosci 17:3128-3135.

Miana-Mena FJ, Roux S, Benichou JC, Osta R, Brulet P (2002) Neuronal activity-dependent membrane traffic at the neuromuscular junction. Proc Natl Acad Sci USA 99:3234-3239.

Moran-Rivard L, Kagawa T, Saueressig H, Gross MK, Burrill J, Goulding M (2001) Evxl is a postmitotic determinant of V0 interneuron identity in the spinal cord. Neuron 29:385-399.

Osumi N, Hirota A, Ohuchi H, Nakafuku M, Iimura T, Kuratani S, Fujiwara M, Noji S, Eto K (1997) Pax-6 is involved in the specification of hindbrain motor neuron subtype. Development 124:2961-2972.

Penzes P, Beeser A, Chernoff J, Schiller MP, Eipper BA, Mains RE, Haganir R (2003) Rapid induction of dendritic spine morphogenesis by transsynaptic EphrinB-EphB receptor activation of the Rho-GEF kalirin. Neuron 37:263-274.

Rajewsky K, Gu H, Kuhn R (1996) Conditional gene targeting. J Clin Invest 98:600-603.

Renshaw B (1946) Central effects of centripetal impulses in axons of spinal ventral roots. J Neurophysiol 9:191-204.

Saueressig H, Burrill J, Goulding M (1999) Engrailed-1 and Netrin-1 regulate axon pathfinding by association interneurons that project to motor neurons. Development 126:4201-4212.

Schneider SP, Fyffe REW (1992) Involvement of GABA and glycine in recurrent inhibition of spinal motor neurons. J Neurophysiol 68:397-406.

Sharma K, Peng CY (2001) Spinal motor circuits: merging development and function. Neuron 29:321-324.

Soriano P (1999) Generalized lacZ expression with the ROSA26 Cre reporter strain. Nat Genet 21:70-71.

Vallstedt A, Muhr J, Pattyn A, Pierani A, Mendelson M, Sander M, Jessell TM, Ericson J (2001) Different levels of repressor activity assign redundant and specific roles to $N k x 6$ genes in motor neuron and interneuron specification. Neuron 31:743-755.

Wenner P, O'Donovan MJ, Matise MP (2000) Topographical and physiological characterization of interneurons that express engrailed-1 in the embryonic chick spinal cord. J Neurophysiol 84:2651-2657.

Yoshihara Y, Mizuno T, Nakahira M, Kawasaki M, Watanabe Y, Kagamiyama H, Jishage K, Uedo O, Suzuki H, Tabuchi K, Sawamoto K, Okano H, Noda T, Mori K (1999) A genetic approach to visualization of multisynaptic neural pathways using plant lectin transgene. Neuron 22:33-41. 